\title{
Arrangement Plan of Inner Mongolia Buddhist Temple
}

\author{
By Enke Haoribao*, Yoshinori Natsume ${ }^{ \pm} \&$ Shinichi Hamada ${ }^{*}$ \\ Since BC, the construction of cities has been started in the Mongolian Plateau \\ with the establishment of dynasties, but many were turned into ruins. However, \\ the Tibetan Buddhist temples built after the 16th century, which are an \\ indispensable element in the process of settling the Mongolians from nomadic \\ life, have been relatively well preserved in Inner Mongolia. These temples have \\ been thought to be the epitome of the Mongolian economy, culture, art, and \\ construction technology. Therefore, it has a great significance to research them \\ systematically. Interestingly, these temples in Mongolia were originated from \\ Inner Mongolia, which is located on the south side of Mongolia. The architectural \\ design of these temples has been primarily influenced by Chinese and Tibetan \\ temple architecture, suggesting that the temples appear to be considered a vital \\ sample for studying temple architecture in Mongolia or East Asia. So far, there \\ is still no study systematically on temple architecture in Inner Mongolia. \\ Therefore, this research aims to study the arrangement plan of Inner Mongolian \\ Tibetan Buddhist temples, which is the most important factor to consider in the \\ first stage of temple construction.
}

\section{Introduction}

On the Mongolian Plateau, cities have been constructed with the establishment of dynasties Since BC, but most turned to ruins, and a few old buildings still exist. ${ }^{1}$ Under such circumstances, the temple buildings that were built after the 16th century occupy the majority. ${ }^{2}$ According to data, up to the 19th century, more than 1,200 temples in Inner Mongolia, more than 700 temples in Mongolia, and more than 100,000 monks in Inner Mongolia were confirmed ${ }^{3}$. These temples were built by combining the power of each level of society and are considered the epitome of the Mongolian economy, culture, art, and construction technology of the time. The Mongolian region after the Yuan Dynasty corresponds to a wide area like the present Inner Mongolia Autonomous Region and Xinjiang Uygur Autonomous Region of the People's Republic of China, Mongolia, and the Republic of Buryatia, Republic of Tuva, and the Republic of Kalmykia in the Russian Federation. ${ }^{4}$ However, many Buddhist temples in these countries and regions were destroyed by religious persecution caused by Soviet Socialism ${ }^{5}$ or the Cultural Revolution in China.

* Graduate Student, Nagoya Institute of Technology, Japan.

${ }^{ \pm}$Associate Professor, Nagoya Institute of Technology, Japan.

${ }^{\star}$ Associate Professor, Nagoya Institute of Technology, Japan.

1. N. Tsultem, Mongolian Architecture (Ulan-Bator: State Publishing House, 1988), 2-3.

2. Yuhuan Zhang, Inner Mongolian Ancient Architecture (Tianjin University Press, 2009), 1-9.

3. Rasurong, Daci Temple-Hyangarwa (Inner Mongolia Culture Press, 2013), 2-31.

4. Baichun Wu, A Brief History of the Mongolian Empire (Inner Mongolia People's Publishing House, 2011), 31-42.

5. Н. Baasansuren, Erdene Zuu: The Jewel of Enlightenment 《Позитив》 агентлаг, 2011), 13. 
Interestingly, these temples originated from Inner Mongolia, the southern part of Mongolia. And the architectural design of these temples has been primarily influenced by the architecture of Han Buddhist temples and Tibetan temples. Therefore, these temples' architecture is considered a vital sample for studying temple architecture in Mongolia and East Asia. Until now, these temples have been relatively well preserved for a long time, fortunately. Yet, due to there is still no systematic study on this subject, the value of these old buildings is not widely recognized by society, there are many cases where they are demolished during repairs.

Therefore, there is great value and significance to study the temples of Inner Mongolia and systematically clarify the characteristics of Mongolian temple architecture not only in Mongolia but also in the architectural history of East Asia, and there is an urgent need to make the value known to society. This study focuses on Buddhist temples in the Inner Mongolia region and considers the arrangement plan of the temple, which is the most important aspect in the design and first stage of temple construction.

\section{Literature Review}

The previous study on the architecture of the Tibet Buddhist temple in Inner Mongolia is mainly summarized in two studies, mainly by Japanese and Chinese researchers.

Studies of Japanese researchers are "Notes of the Mongolian Plateau Crossing"6 by Mongolian investigation class of Eastern Archaeological Society of Japan in 1930-1940, "Mongolian Academic Temple"7 by Gajin Nagao, a Buddhist scholar from Eastern Culture Research Institute, "Mongolian Buddhist travelogue" 8 by Akira Suganuma, "A Comprehensive Survey of Buddhist Temples at Western Inner Mongolia: A Study on the History of Mongolian Buddhist Architecture (Part 1)"9 and "The process for Establishment of Buddhist Temple Ushin Dzuu and Its Spatial Structure: A Study on the History of Mongolian Buddhist Architecture (Part 2)"10 by Bao Muping.

These studies are valuable materials that record the appearance of temple architecture at that time. Still, they are limited to a few temples in Inner Mongolia and have not yet clarified the characteristics of the whole Inner Mongolia temple.

6. Toa Archaeology Society Mongolian Survey Group, Notes of the Mongolian Plateau Crossing (Asahi Shimbun Press, 1945).

7. Nagao Gajin, Mongolian Academic Temple (Chuko Bunko, 1992).

8. Suganuma Akira, Mongolian Buddhist Travelogue (Shunmei Sha, 2004).

9. Muping Bao, "A Comprehensive Survey of Buddhist Temples at Western Inner Mongolia: A Study on the History of Mongolian Buddhist Architecture (Part 1)," in Summaries of Technical Papers of Annual Meeting, 193-194 (Architectural Institute of Japan, 2007).

10. Bao, "The Process for Establishment of Buddhist Temple Ushin Dzuu and its Spatial Structure: A Study on the History of Mongolian Buddhist Architecture (Part 2)," in Summaries of Technical Papers of Annual Meeting, 195-196 (Architectural Institute of Japan, 2007). 
Studies by Chinese researchers are "Inner Mongolian Ancient architecture"11 by Zhang Yuhuan, "Archaeology of Tibetan Buddhist Temple"" by Su Bai, "Inner Mongolian Tibetan Buddhist Architecture"13 by Zhang Pengju. Among these research surveys, "Inner Mongolian Tibetan Buddhist Architecture" by Zhang Pengju conducts an actual measurement survey of temple architecture in the whole area of Inner Mongolia, organizes photographs and drawings of the building. Although it is possible to grasp the characteristics of temple architecture in a comprehensive manner, it has not yet reached a systematic study on the changes in the times of temple architecture.

There are currently about 110 existing temples built between the 16th and 19th centuries in the Inner Mongolia region. ${ }^{14}$ However, only 30 temples, including ten leagues and cities, can master the situation of each building through their arrangement plan, so this study takes these 30 temples as the research object. Among the 30 temples, there are 9 in Tongliao City and Chifeng City in the eastern region, 10 in Hohhot City, Xilingol League and Ulanqab City in the middle region, and 11 in Alxia League, Ordos City, Bayannaoer City, and Baotou City in the western region (Figure 1).

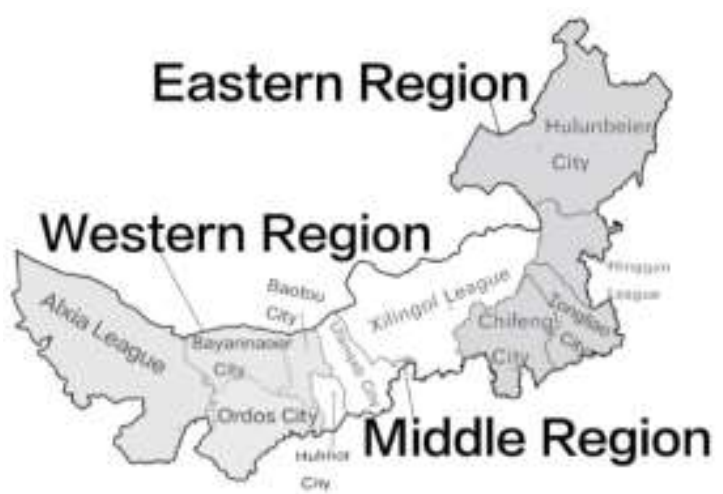

Figure 1. The Map of Inner Mongolia

Source: Drawn by author.

\section{Methodology}

As a research method, Firstly, the temples are divided into different levels according to the historical background of the temples in the part of "the judgment of the temple level'. Further, the temple buildings are also classified based on their functions, in the part of "the classification of temple building". Lastly, the arrangement plan has been modeled to clear the difference between them and clarify the characteristics of the arrangement plan of the Inner Mongolian Buddhist

11. Zhang, Inner Mongolian Ancient Architecture, 2009.

12. Bai Su, Archaeology of Tibetan Buddhist Temple (Cultural Relics Press, 1996).

13. Zhang, Pengju, Inner Mongolian Tibetan Buddhist Architecture (I), (II), (III). (China Architecture \& Building Press, 2013).

14. Pengju Zhang, Inner Mongolian Tibetan Buddhist Architecture (I) (China Architecture \& Building Press, 2013), 6. 
temples by analysis of each type, in the part of "The Classification and analysis of temple arrangement plan”.

\section{The Judgment of Temple Level}

When determining the temple level, it is necessary to consider the Development and Change of Mongolian society's background, as well as the construction background of each temple.

These temples in the Mongolian area were mainly built between the 16th and 19th centuries. Specifically, at first, the Mongolian Khan Altan Khan and Lindan Khan introduced the Gelug Tibetan Buddhism ${ }^{15}$ and Sakya Tibetan Buddhism ${ }^{16}$ respectively in the Mongolian area after the Yuan dynasty. ${ }^{17}$ After that, due to the power of them was subsided, and the intervention to the Mongolian through politics, and religion in the Qing Government, all regions of Inner Mongolia were successively brought under the jurisdiction of the Qing. ${ }^{18}$

In the 17th century, the Gelug Tibetan Buddhism became unreliable on Altan Khan's forces and relied on the powerful Gushi Khan of Oirat Mongolian to become the largest sect of Tibetan Buddhism, and its supreme leader, the Dalai Lama, became the supreme religious leader of all sects of Tibetan Buddhism. ${ }^{19}$

From the Qianlong period ${ }^{20}$ of the Qing Dynasty after the 18th century, Xinjiang, and Qinghai, where the Oirat Mongols lived, and the whole region of Tibet was brought under the jurisdiction of the Qing Dynasty ${ }^{21}$ Under this great background change, in about 300 years, most of the temples in Inner Mongolia were built by Mongolian nobles. Still, in the construction process, they were also influenced by the political influence of the Qing Dynasty from the East and the religious impact of Tibet from the West.

The time from the 16th century to the 19th century is the period from the Northern Yuan Dynasty to the end of the Qing Dynasty in Mongolia, and most of the time in the Qing Dynasty. Therefore, this paper will divide the temple level in Inner Mongolia according to the social background and the construction background of each temple in the Qing Dynasty.

15. The Gelug Tibetan Buddhism was founded by Tibetan philosopher Tsongkhapa in the 15th century, and it is the newest and currently most dominant of Tibetan Buddhism.

16. The Sakya Tibetan Buddhism was founded in the 11th century, and it is one of the major schools of Tibetan Buddhism.

17. Patricia Berger and Terese Tse Bartholomew, Mongolia the Legacy of Chinggis Khan (Hong Kong: C\&C Offset Printing Co., 1995), 1-6.

18 Namusilai, History of Mongolia in Qing Dynasty (Inner Mongolia People's Publishing House, 2011), 1-23.

19. Saiyinchaogetu, The Great Khan in the Late Northern Yuan Dynasty (Inner Mongolia Culture Press, 2014), 104-124.

20. The Qianlong period refers to the reign of Emperor Qianlong of the Qing Dynasty from 1735 to 1796.

21. Namusilai, History of Four Oirat Mongolia (Inner Mongolia People's Publishing House, 2011), 146-160. 
The administrative divisions of the Qing dynasty that governed Mongolia at that time generally had "Province" called "Sheng" under the "State" called "Guo", and had "prefecture" called "Fu" or "Zhou" under the "Province", also had "County" called "Xian". The current Inner Mongolia Autonomous Region and Mongolia were called "Inner Mongolia" and "Outer Mongolia" from the Qing dynasty at that time, and both were equivalent to the administrative divisions of the "Province" of the Qing dynasty. The administrative units equivalent to "Fu" or "Zhou" are called "League" (Aimugu in Mongolian), equal to "Xian" is called "Banner" (Hosho in Mongolian) ${ }^{22}$. It has been used as the name of the administrative divisions of Mongolia and Inner Mongolia Autonomous Region until now. Since Inner Mongolia was an administrative division corresponding to the "Province" of the Qing dynasty, the name of the administrative division "Province" will be treated as the name of the administrative division of the whole of Inner Mongolia in this paper. From the above, based on the social background of the history time and the level of each temple (Table 1) the levels of the Inner Mongolia temples can be summarized as follows: "Province Level Temple", "League Level Temple", and "Banner Level Temple".

There are 4 Province Level temples, Ihezhao Temple, Xiretzhao Temple, Hoh Temple, and Jiang-Jia Hoh Temple, which were built by Mongolian khan and the emperor of the Qing dynasty (Figure 2).

There are 18 League Level temples. In these temples, the Chaganbure Temple belongs to the imperial temple of the Qing dynasty, and the Maidarzhao Temple, Xiaramuren Temple, Osutozhao Temple, Maritui Temple, Badgar Temple belong to the Province Level temples. East Huhger temple, Batahalaga Temple, Fuhui Temple, Lingyue Temple, Maritu Temple, Merigen Temple, Zhungaarzhao Temple, Yamen Temple were built by the nobles of Leagues, and Xingyuan temple was constructed by the high-ranking Hutuhetu. Xiaramuren Temple, Shaletew Temple, Beis Temple have subordinate temples (Figures 3 and 4).

There are 8 Banner Level temples. In these temples, Changshou Temple, Faxi Temple, Agui Temple, Badanjiren Temple, and Fuyuan Temple belong to the League Level temples, and the Balaqirude Temple built by the local Hutehetu, and Xiara Temple and Han Temple were built by the local nobility of each Banner ${ }^{23}$ (Figure 5).

22. Miyawaki Junko, History of Mongolia-From the Birth of Nomads to Mongolia (Toui Shobo, 2002, 10), 219-220.

23. The Judgment of Province level, League Level, and Banner Level temples are mainly based on the contents of the background of each temple written by Zhang, Inner Mongolian Tibetan Buddhist Architecture (I), (II), (III), 2013. 
Table 1. List of Temples Classified by Temple Level

\begin{tabular}{|c|c|c|c|c|c|}
\hline No. & Temple Level & Temple Name & Built & Location & Remarks \\
\hline 1 & \multirow{4}{*}{ Province Level } & Ihezhao Temple & 1578 & Huhhot City in Middle Region & Mongolian first tibetan buddist temple built by Altan Khan \\
\hline 2 & & Xiretzhao Temple & 1585 & Huhhot City in Middle Region & The temple Where the Fourth Dalai Lama ascended the throne \\
\hline 3 & & Hoh Temple & 1691 & Xilingol League in Middle Region & The temple built by the Qing Emperor for Jetsun Dampa Hutuhetu \\
\hline 4 & & Jiang-Jia Hoh Temple & 1701 & Xilingol League in Middle Region & The temple built by the Qing Emperor gor Jiang-Jia Hutuhetu \\
\hline 5 & \multirow{18}{*}{ League Level } & Chaganbure Temple & 1743 & Chifeng City in Eastren Region & The temple belongs to the Yonghe Temple \\
\hline 6 & & Maidarzhao Temple & 1606 & Baotou City in Western Region & The temple belongs to the Xiretzhao Temple \\
\hline 7 & & Xiaramuren Temple & 1769 & Baotou City in Western Region & The temple belongs to the Xiretzhao Temple \\
\hline 8 & & Osutozhao Temple & 1606 & Huhhot City in Middle Region & The temple belongs to the Xiretzhao Temple \\
\hline 9 & & Maritu Temple & 1729 & Baotou City in Western Region & The temple belongs to the Xiretzhao Temple \\
\hline 10 & & Badgar Temple & 1749 & Baotou City in Western Region & The temple belongs to the Jiang-Jia Hoh Temple \\
\hline 11 & & East Huhger Temple & 1706 & Chifeng City in Eastern Region & Built by Gulun Princess who is the Emperor Kangxi's third daughter \\
\hline 12 & & Batahalaga Temple & 1702 & Baotou City in Western Region & Built by the noble of Halaha Mongols \\
\hline 13 & & Fuhui Temple & 1679 & Chifeng City in Eastern Region & Built by the noble of Right Horchin Mongols \\
\hline 14 & & Lingyue Temple & $\begin{array}{l}1692- \\
1711 \\
\end{array}$ & Chifeng City in Eastern Region & Built by the nobles of Right Horchin Mongols as a palae building \\
\hline 15 & & Maritu Temple & 1745 & Chifeng City in Eastern Region & Built by the nobles of Middle Horchin Mongols \\
\hline 16 & & Merigen Temple & $\begin{array}{l}1692- \\
1722 \\
\end{array}$ & Baotou City in Western Region & $\begin{array}{l}\text { The temple built by the nobles of Wurat Mongols and it has } 5 \\
\text { subordinate temples }\end{array}$ \\
\hline 17 & & Zhungaarzhao Temple & 1623 & Ordos City in Western Region & $\begin{array}{l}\text { The temple built by the nobles of Jungaar Mongols and it has } 18 \\
\text { subordinate Temples }\end{array}$ \\
\hline 18 & & Yamen Temple & 1731 & Alxia League in Western Region & $\begin{array}{l}\text { The temple built by the nobles of Hushuut Mongols and it has } 11 \\
\text { subordinate Temples }\end{array}$ \\
\hline 19 & & Xingyuan Temple & 1649 & Tongliao City in Eastern Region & $\begin{array}{l}\text { Built by the Jiasag Da Lama Hotogtu who has actual control over } \\
\text { local religion and politics }\end{array}$ \\
\hline 20 & & Xiaramuren Temple & 1708 & Ulanqab City in Middle Region & $\begin{array}{l}\text { The temple manages some temples in central Inner Mongolia and } \\
\text { Qinghai }\end{array}$ \\
\hline 21 & & Shaletew Temple & 1723 & Bayannaoer City in Western Region & The temple has 3 subordinate temples \\
\hline 22 & & Beis Temple & 1743 & Xilingol League in Middle Region & The temple has 1 subordinate temple \\
\hline 23 & \multirow{8}{*}{ Banner Level } & Changshou Temple & 1697 & Huhhot City in Middle Region & The temple belongs to the Osutozhao Temple \\
\hline 24 & & Faxi Temple & 1725 & Huhhot City in Middle Region & The temple belongs to the Osutozhao Temple \\
\hline 25 & & Agui Temple & 1803 & Bayannaoer City in Western Region & The temple belongs to the Yamon Temple \\
\hline 26 & & Badanjiren Temple & 1755 & Alxia League in Western Region & The temple belongs to the Yamon Temple \\
\hline 27 & & Fuyuan Temple & 1742 & Tongliao City in Eastern Region & The temple belongs to the Xingyuan Temple \\
\hline 28 & & Balaqirude Temple & 1770 & Tongliao City in Eastern Region & $\begin{array}{l}\text { Built by the attendants of the Qing dynasty princess and the local } \\
\text { Hutuhetu }\end{array}$ \\
\hline 29 & & Xiara Temple & 1864 & Xilingol League in Middle Region & Built by the local nobility \\
\hline 30 & & Han Temple & 1671 & Tongliao City in Eastern Region & Built by the local Hutuhetu \\
\hline
\end{tabular}

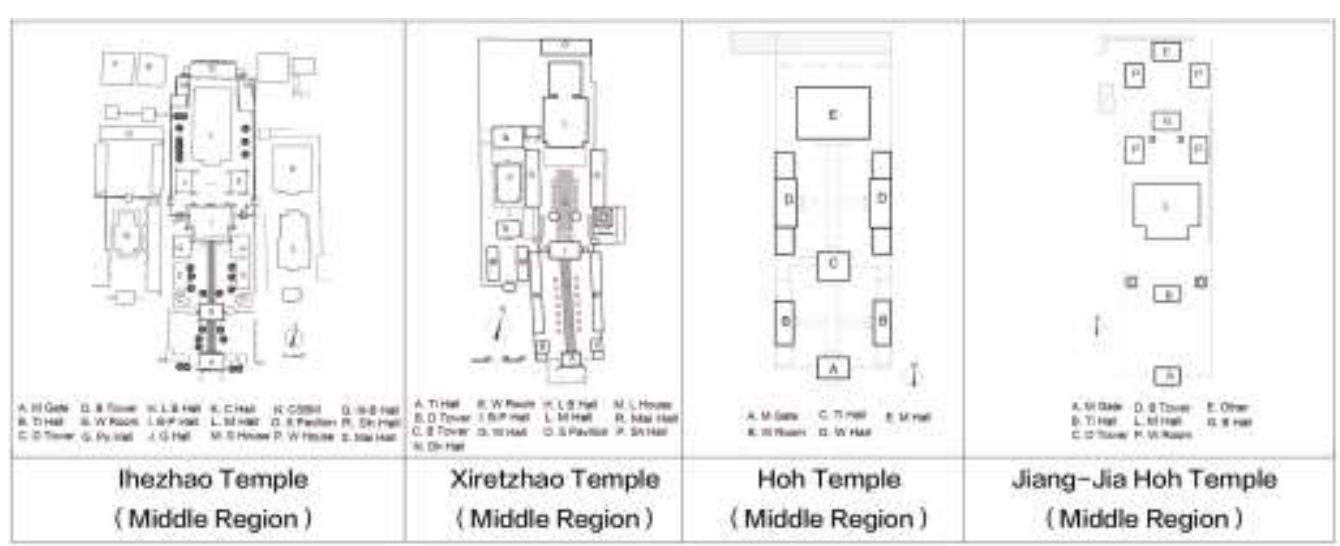

Figure 2. The Arrangement Plan of Province Level Temples

Source: Inner Mongolian Tibetan Buddhist Architecture (I), (II), (III). 


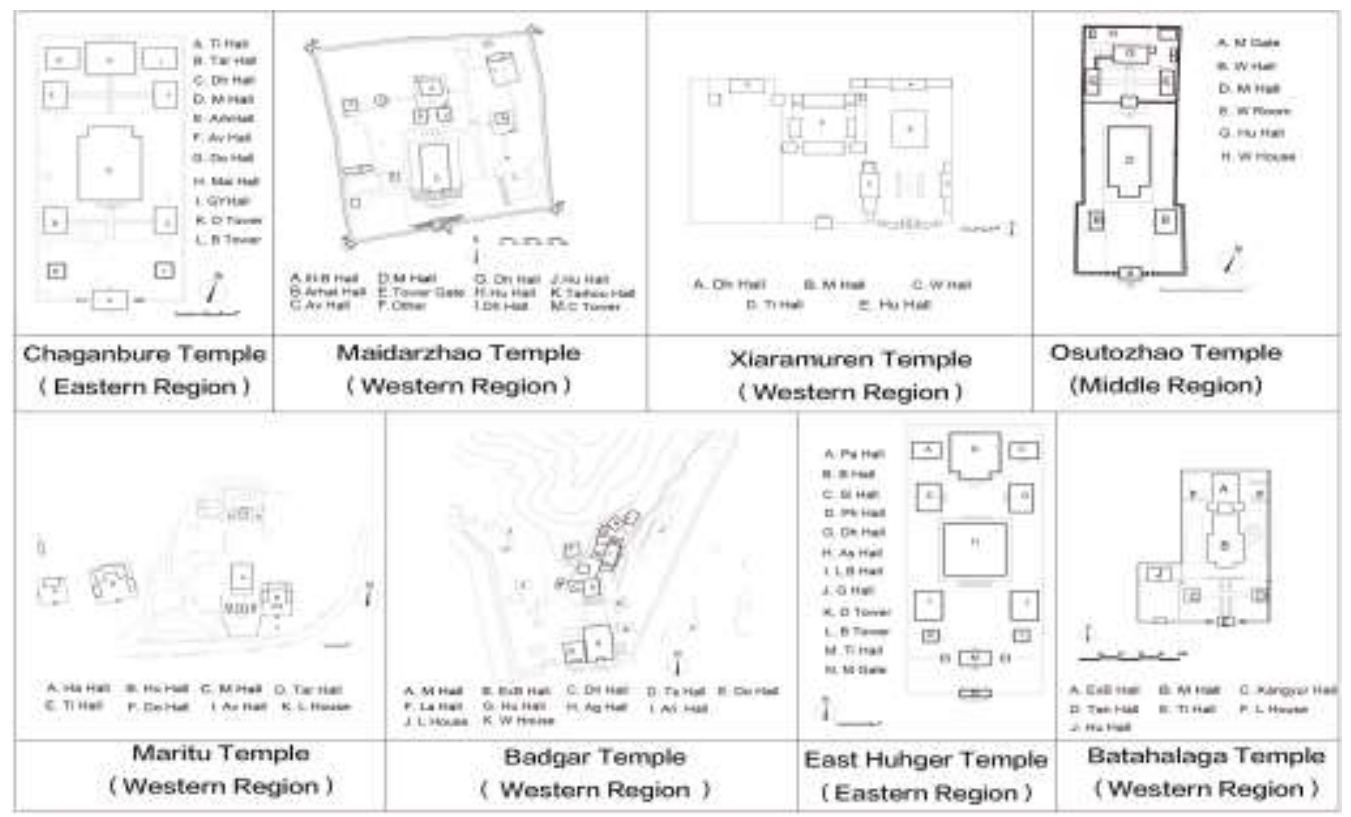

Figure 3. The Arrangement Plan of League Level Temples 1-8

Source: Inner Mongolian Tibetan Buddhist Architecture (I), (II), (III).

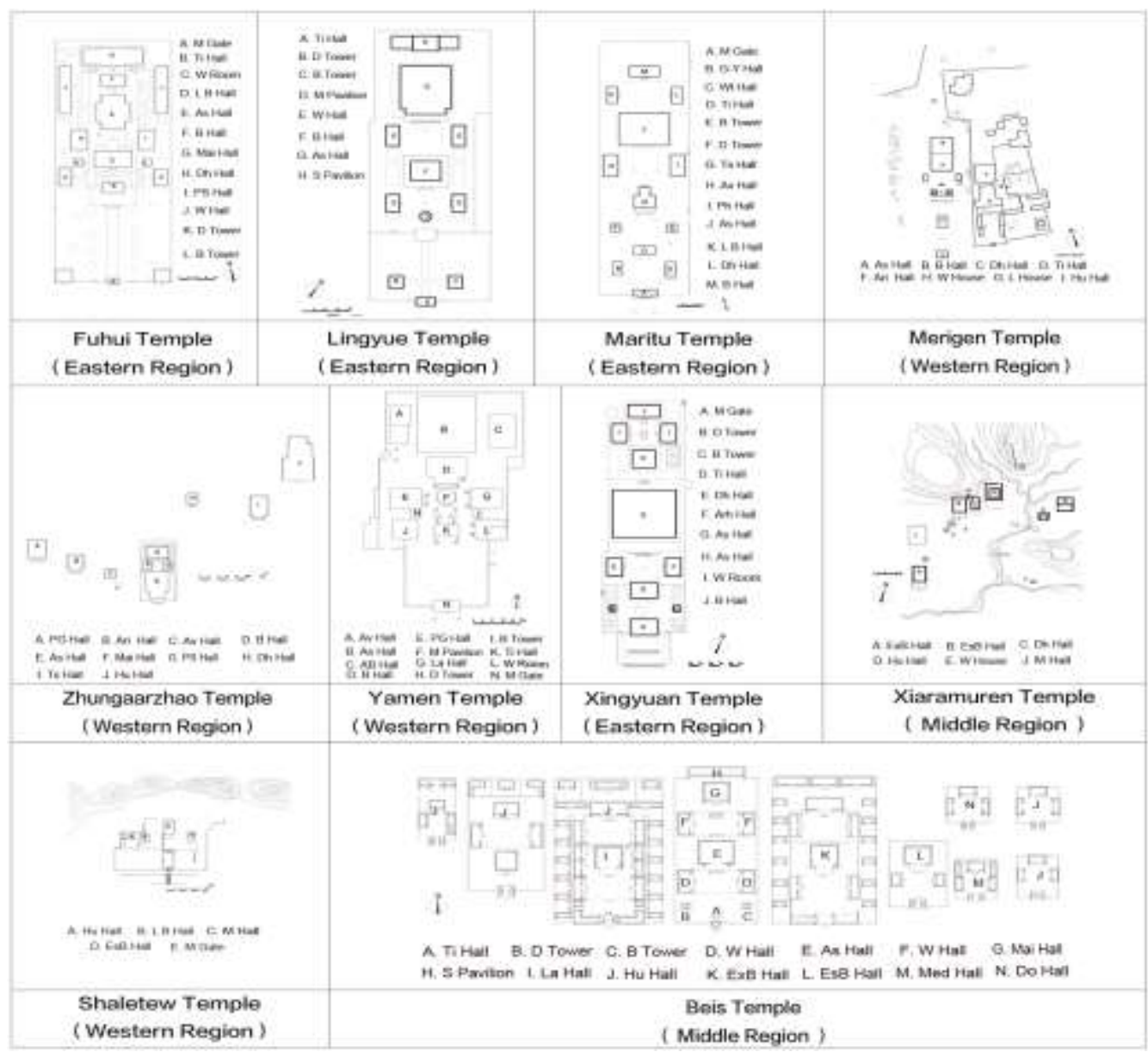

Figure 4. The Arrangement Plan of League Level Temples 9-18

Source: Inner Mongolian Tibetan Buddhist Architecture (I), (II), (III). 


\section{The Classification of Temple Building}

The architecture of the target temple has 56 types classified by the name, function, Buddha statue enshrined inside. It can be roughly divided into three types according to the primary purpose of each building (Table 2).

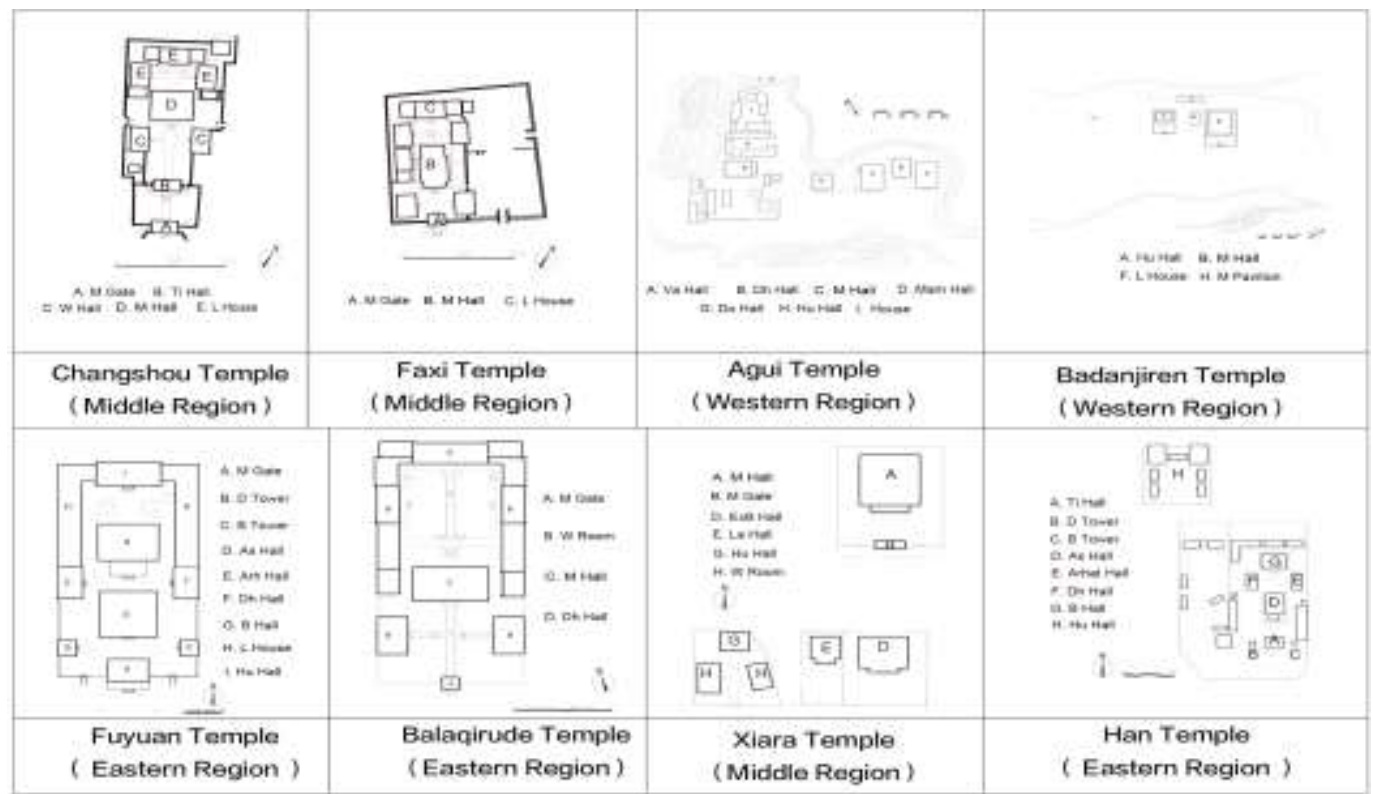

Figure 5. The Arrangement Plan of Banner Level Temples

Source: Inner Mongolian Tibetan Buddhist Architecture (I), (II), (III).

First, the Class I is to place Buddha statues. According to the level of Buddha statues, they are the Honzon, the Tathagata, the Bodhisattva, the Vajra, the Mother Buddha, the Local Buddha, the Disciple, the Patriarch, the Four Heavenly Kings, and the Hutuhetu. According to the level of the Buddha statues, these buildings can be further divided into six groups. The first group is the Mahavira Hall and Buddha Hall, dedicated to the Honzon, the most important Buddha statue of the temple. The second group is the buildings dedicated to the Buddha statues of the Tathagata or Bodhisattva, which are not the Honzon of the temple. The third group is the Vajra and the Buddha mother, which are regarded as the incarnation of the Tathagata and Bodhisattva and the Disciples, the Patriarch. The fourth and the fifth group are the Tianwang Hall dedicated to the Four Heavenly Kings guarding the temple and the Hutuhetu Hall. The sixth group is the building where the Buddha statues cannot be distinguished, such as the Wing Hall. ${ }^{24}$

Class II is for religious ceremonies such as sermons, worship, and ceremonies, and it consists of the below four groups of buildings. Assembly Hall and Buddhism Hall are for teaching Buddhist chanting and Buddhist scholarship. The Sutra

24. Wing Hall is called "Jiguurin Dugan" in Mongolian, and it is translated as "Wing Hall" by the mean of the building's name. Although it can also be translated as the "Pei Dian" in Chinese, it generally refers to the "Dharmapalas Hall" and the "Patriarch Hall" in Han Buddhist temple. Still, there are not only these two Hall in Mongolian temples. Therefore, this paper uses the name of "Wing Hall" to differentiate them. 
Pavilion, the Mani Pavilionare, the Tangyur Hall, and the Kangyur Hall preserve the scriptures. ${ }^{25}$ The Bell Tower and the Drum Tower are used for time signals and ceremonies. The Arira Hall, the Arira Tower and the Taihou Hall are used for worship.

Class III is the attached building, and it consists of the below three groups of buildings. The Monastery Gate, the Tower Gates, the Corner Tower are for protecting the site. The Wing room and the Lama house for customers and people to live. The Supporting House and the Buddhist Items House, the Warehouse are all used as a storeroom.

In the Mongolian temple, the Mahavira Hall of class I is Integration of the Buddha Hall and the Assembly Hall. Moreover, the Buddha Hall dedicates the Honzon of the temple. The Assembly Hall of class II is where the monks gather and read the scriptures every day. So, these three buildings are the most critical three buildings of all the temple buildings. Furthermore, when the Buddha Hall and the Assembly Hall are integrated, it is arranged as the Mahavira Hall, and when the Buddha Hall and the Assembly Hall are separated, there is no Mahavira Hall in the temple.

Table 2. List of the Temple Buildings Classed by Function

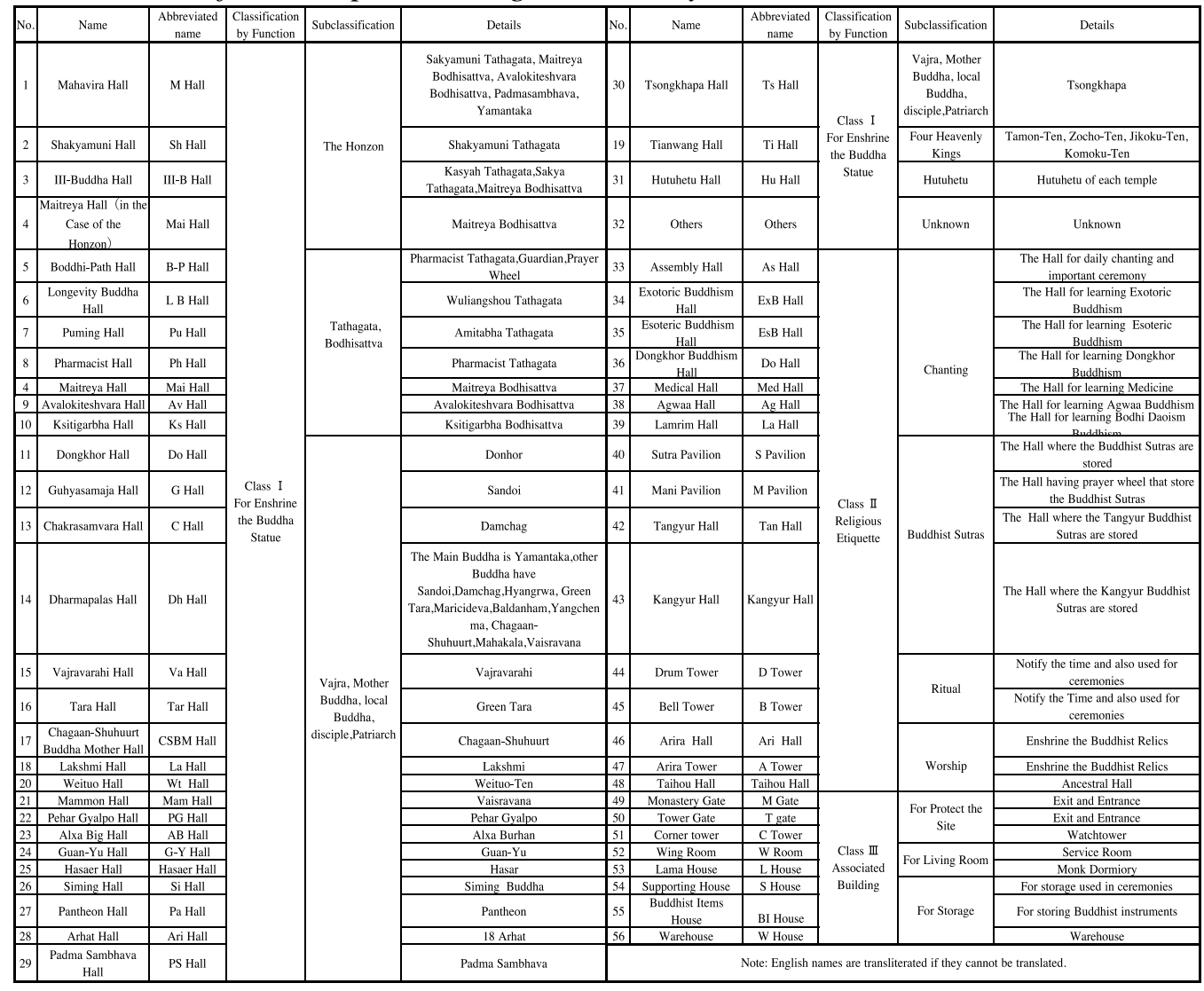

25. Kangyur Hall and Tangyur Hall are buildings that preserve the Kangyur Buddhist Sutras and Tangyur Buddhist Sutras. The Kangyur Buddhist Sutras and Tangyur Buddhist Sutras are the rules, sutras, and essays of the Tibetan Buddhist Canon. 


\section{The Classification and Analysis of Temple Arrangement Plan}

Based on the distinction of temple level and the classification of buildings, the arrangement of each temple is categorized.

Firstly, according to the temple level, the temples can be roughly classified into three types, Province Level Temple, League Level Temple, and Banner Level Temple.

Secondly, according to the relation between the most important building, the Mahavira Hall, the Buddha Hall, and the Assembly Hall, the temples can be classified into five types. Specifically, the temple form with the Mahavira Hall, which is integrated by the Buddha Hall and the Assembly Hall, and the temple form that the Buddha Hall and the Assembly Hall are separated are defined as Integrated Type and Separated Type. So, these temples can be classified as Integrated Type and Separated Type.

Furthermore, the temples can be classified into the symmetric type and asymmetric type depending on whether the buildings are arranged symmetrically along the axis. Finally, it can be divided into seven types according to the temple's level and architecture (Table 3). Then, arrangement plan of the seven types is modeled in order to clarify the characteristics ${ }^{26}$ (Figure 6). In order to make the building names easy to distinguish, the abbreviated names of all buildings are adopted in the Model Figure of each temple's arrangement. Please refer to the abbreviated names of each building in Table 2 .

Table 3. List of Temples Classified by Arrangement Plan

\begin{tabular}{|c|c|c|c|c|c|}
\hline Temple Level & Number & Type & Number & Detailed Type & Number \\
\hline Province Level & 4 & Integrated & 4 & Symmetric & 4 \\
\hline \multirow{3}{*}{ League Level } & \multirow{2}{*}{18} & \multirow{2}{*}{ Integrated } & \multirow{2}{*}{9} & Symmetric & 7 \\
\cline { 3 - 6 } & & Seperated & 9 & Asymmetric & 2 \\
\hline \multirow{2}{*}{ Banner Level } & \multirow{2}{*}{8} & Integrated & \multirow{2}{*}{6} & Symmetric & 9 \\
\cline { 5 - 6 } & & Seperated & 2 & Asymmetric & 2 \\
\cline { 4 - 6 } & & & \multicolumn{3}{|c}{} \\
\hline
\end{tabular}

26. The model figure showing the arrangement of the temples are mainly created by referring to the arrangement plan of each temple written in books, such as Inner Mongolian Tibetan Buddhist Architecture (I), (II), (III) by Zhang Pengju, Mongolian Academic Temple by Gajin Nagao, Mongolian Buddhist Travelogue by Akira Suganuma. 


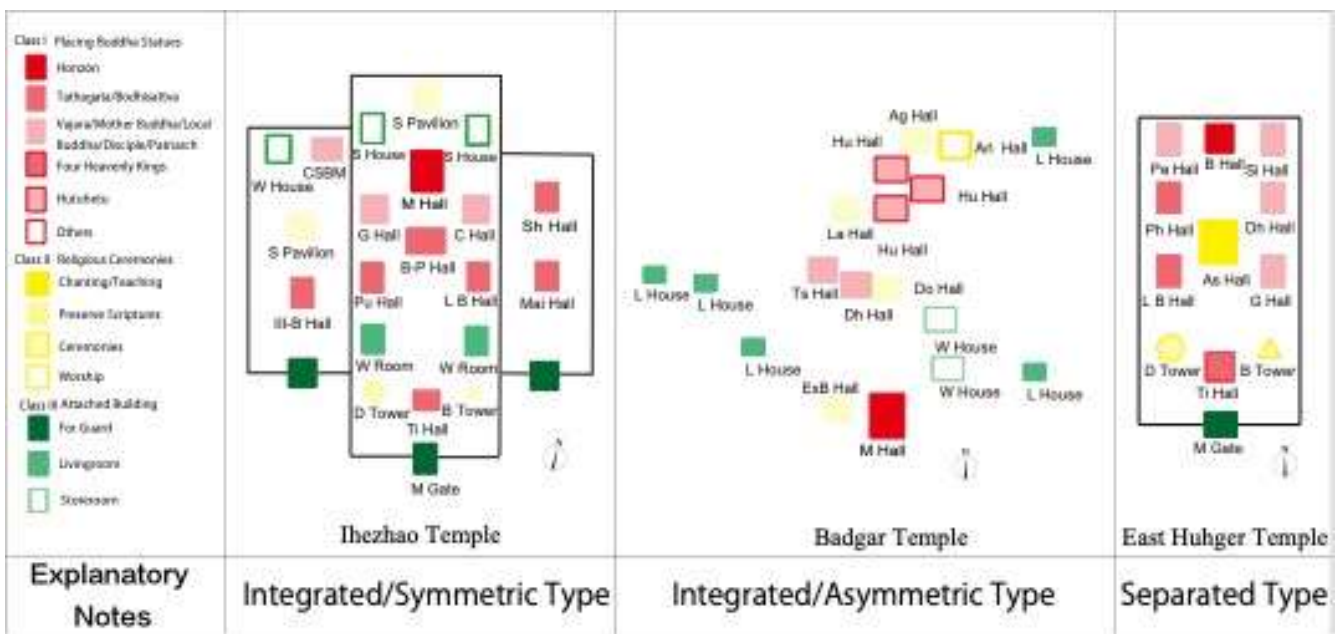

Figure 6. Legend of Model Figure Created by Arrangement o Temples

Source: Inner Mongolian Tibetan Buddhist Architecture (I), (II), (III).

\section{The Province Level Temple}

There are four Province Level temples, all of which are Integrated and Symmetric Type. All the buildings are arranged symmetrically along the axis. Among them, many temples are equipped with buildings of Class I, II, III, the site is surrounded by walls, the Monastery Gate and the Tianwang Hall is always built on the front side, and Bell Tower and Drum Tower are built symmetrically on both sides behind it, and Wing house is built further behind. Moreover, these characteristics are the same as the arrangement of Han Buddhist temples, which has the following characteristics:

- All the buildings are arranged symmetrically and orderly along the axis.

- Walls surround the temple site. ${ }^{27}$

- The Monastery Gate or Tianwang Hall are equipped in front of the site.

- The Bell Tower and Drum Tower are built symmetrically on both sides behind the Tianwang Hall.

Due to the characteristics of these temple arrangement plans are the same as the arrangement plan of the Han Buddhist temples (hereinafter referred to as the Han Buddhist temple style), it is considered that they were built based on the arrangement plan of the Han Buddhist temple style (Figure 7). 


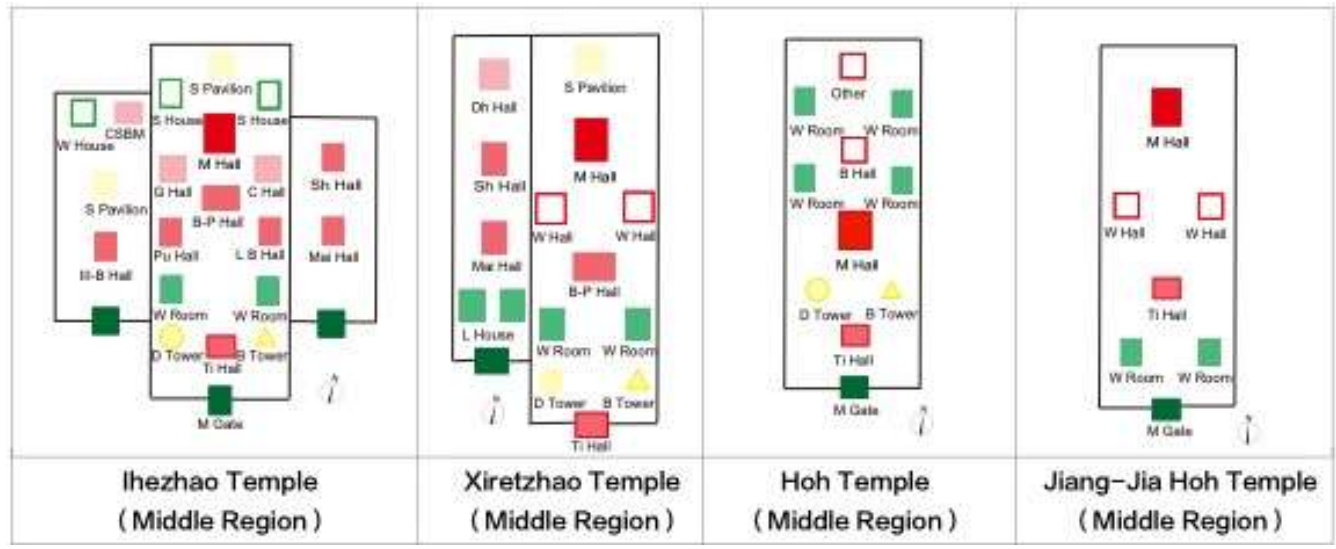

Figure 7. Model of Province Temples

Source: Inner Mongolian Tibetan Buddhist Architecture (I), (II), (III).

Furthermore, the Ihezhao Temple (Figure 8) and Xiretzhao Temple are the oldest Tibetan Buddhist temples in Mongolia, so they are the birthplace of Tibetan Buddhism in Mongolia. Therefore, it is a place where translate and print Tibetan scriptures to each region in the Mongolian area. And also in order to demonstrate the authority of Altan Khan, and his grandson became the supreme leader of Tibetan Buddhism, the fourth Dalai Lama, the two temples were built with all the resources of Mongolian society at that time. So they have become the highest level temple with numerous buildings among all temples in Inner Mongolia.

The Hoh Temple, and Jiang-Jia Hoh Temple, which were built later by the emperor of the Qing dynasty after the war with the Oirat Mongols, to give preferential treatment to the Hutuhetu of Mongolia. Although these two temples were built for the highest-ranking Hutuhetu in Mongolia at that time, due to the investment and construction of the Qing Dynasty had just ended the war with the Oirat Mongols, Mongolia was still in a period of turbulence, they were not built as magnificent as the temples built by the Khan of Mongolia.

From above, it shows that the arrangement plan of the temple at the same level is also different due to different builders and periods.

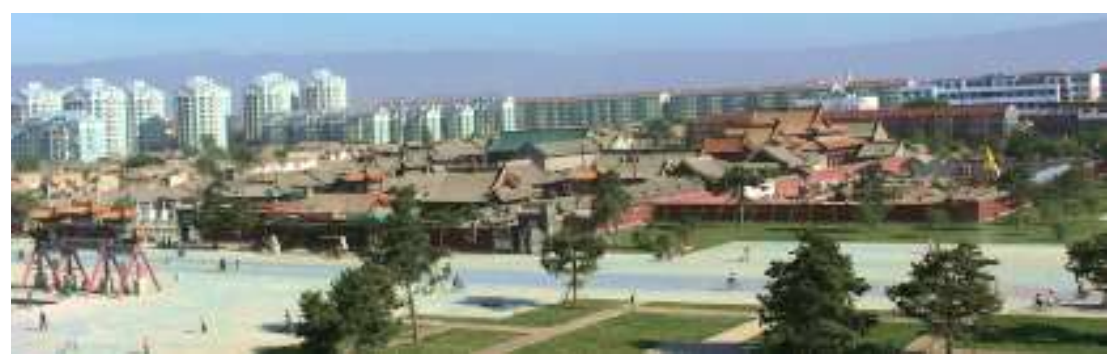

Figure 8. Ihezhao Temple

Source: Inner Mongolian Tibetan Buddhist Architecture (I), (II), (III). 


\section{The League Level Temple}

There are 18 League Level Temple. In these temples, it can be confirmed that seven temples are the Integrated/Symmetric Type Temple, two temples are Integrated/ Asymmetric Type Temples, and the left nine temples are Separated Type Temples.

The Integrated/Symmetric Type

Among the seven temples of this type, five are in the western region, and one is in the middle and eastern regions (Figure 9). Except for the Chaganbure Temple, in the other six temples, the main buildings are arranged along the axis, and the Monastery Gate or Tianwang Hall are equipped in front of the site. This characteristic is the same as the characteristics of the Han-Buddhist-temple style. However, they also have other following characteristics that differ from the HanBuddhist-temple style.

1. As the building moves away from the axis, and minor level buildings are freely allocated.

2. The Bell Tower or Drum Tower are omitted.

3. Compare with the Province Level temples, due to the buildings that dedicate high-level Buddha statues such as Tathagata and Bodhisattva are also omitted, the number of buildings is reduced.

4. The Hutuhetu Hall, which is not found in the Province Level Temple, is located away from the Mahavira Hall, and the Buddhism Hall also.

Furthermore, these characteristics of the arrangement plan are the same as the characteristics of temples in Tibet. There are few regulations on the architectural arrangement and attach importance to the arrangement of buildings related to the education of Buddhism, such as Hutuhetu Hall, Exoteric Buddhism Hall, Esoteric Buddhism Hall. Due to the characteristics of these temples' arrangement plans that not only have the Style of Han Buddhist temples but also have the Style of Tibetan temples, it is considered that the arrangement plan is combined of both (hereinafter referred to as the Compromise temple style).

In fact, it can be seen from the background of these temples that many of them are in the western region and belong to the temple founded by Mongolian Khan. such as the Maidarzhao Temple (Figure 10), Xiaramuren Temple, Osutozhao Temple, Maritui Temple belong to the Xiretzhao Temple of Province Level Temple. Therefore, these temples are not constrained by the architectural form of Han Buddhist temples in the East and are more integrated into the characteristics of arrangement plans in Tibet.

However, the Chaganbure Temple that belongs to the Yonghe temple in Qing Dynasty is constrained by the architectural form of Han Buddhist temples strongly. The arrangement plan is the same as the Province Temple, a Symmetric Type. All the buildings are arranged symmetrically and neatly along the axis, and walls surround the site. The Tianwang Hall is always built on the front side, and Bell 
Tower and Drum Tower are built symmetrically on both sides behind it, which is the same as the Han Buddhist temple style (Figure 11).

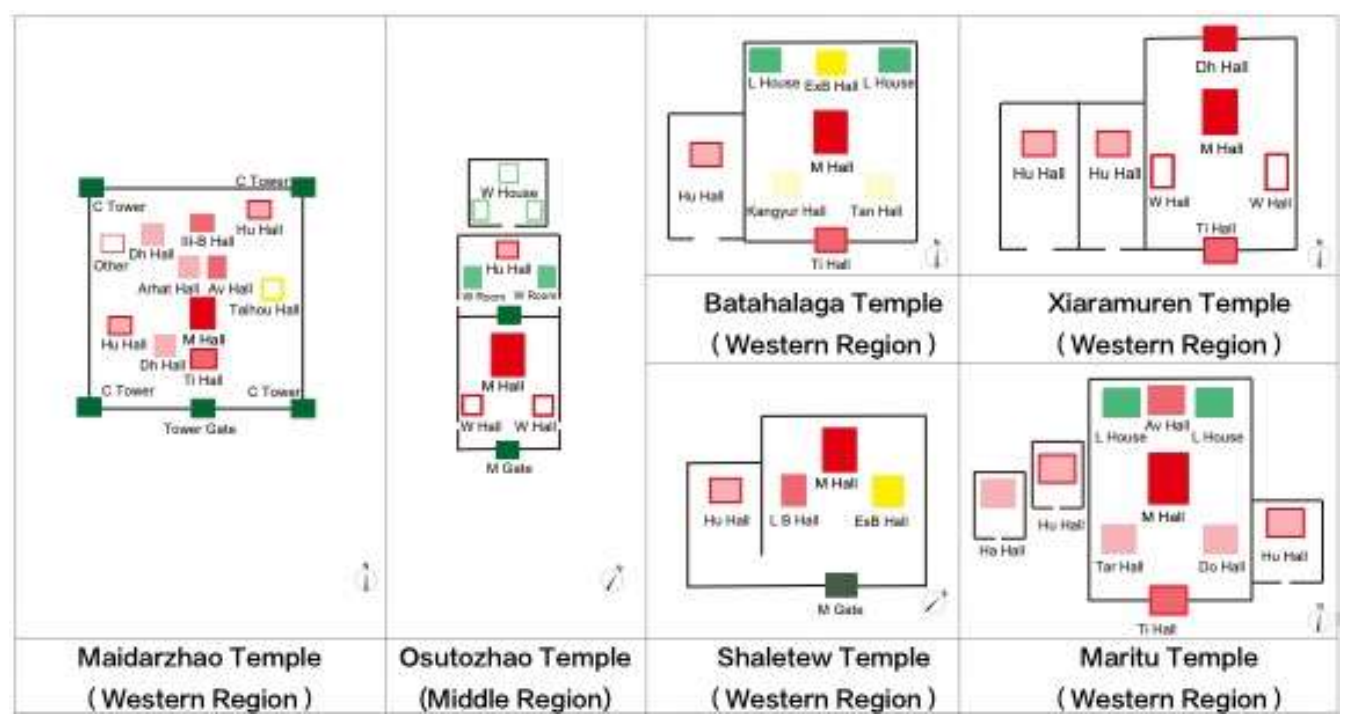

Figure 9. Model Figure of League Level/Integrated/Symmetric Type Temples

Source: Inner Mongolian Tibetan Buddhist Architecture (I), (II), (III).

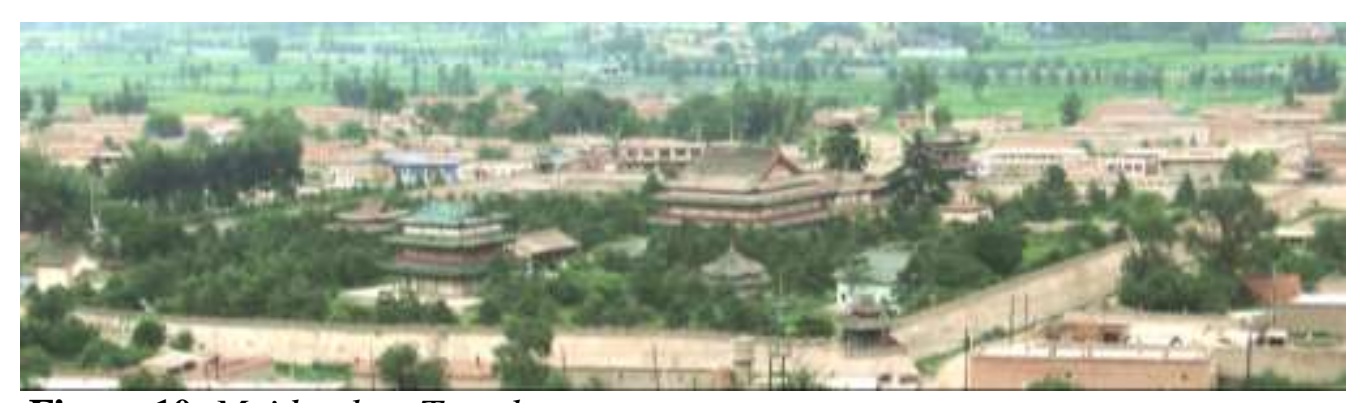

Figure 10. Maidarzhao Temple

Source: Inner Mongolian Tibetan Buddhist Architecture (I), (II), (III).

The Integrated/Asymmetric Type

In this form, the Xiaramuren temple and Badgar temple buildings are freely arranged along the terrain, and the walls are surrounding the site, the Monastery Gate, the Tianwang Hall, the Bell Tower, and the Drum Tower, are omitted. In addition to the Mahavira Hall, the Dharmapalas Hall, and the Hutuhetu Hall, the buildings dedicated to other Buddha statues were also omitted. However, the Buddhism Hall, the Lama House, and the Warehouse are all located, and it has a high attribute of the Academic Temple ${ }^{28}$ that emphasizes academic professors (Figure12). In both cases, the Mahavira and the Exotoric Buddhism Hall are built

28. The Academic Temple is a temple that worships religions every day like other temples, but at the same time consists of several faculties such as Exotoric Buddhism, Esoteric Buddhism, and other faculties, and emphasizes academic professors. Nagao, Mongolian Academic Temple, 1992, 5557. 
in front to show off the temple's authority, and the Hutuhetu Hall is built in the back of the site to concentrate on the work of the live Buddha.

These temples do have not the characteristics of the Han Buddhist temple style. All of them have the following characteristics of the Tibetan temple arrangement plan (hereinafter referred to as the Tibetan temple style).

1. All buildings are freely arranged along the terrain. ${ }^{29}$

2. There is no wall surrounding the site.

3. Buildings such as the Monastery Gate, Tianwang Hall, Bell Tower, and Drum Tower are omitted.

4. There are few types of buildings dedicated to Buddha statues.

5. There will always be the Buddhism Hall that teaches academics and The Hutuhetu Hall.

The reason why the Xiaramuren temple and Badgar temple (Figure 13) were built in this way was determined by the time and location fo construction. They were built in the middle of the 18th century in the western region. It is the Qianlong period of the Qing Dynasty; the whole region of Tibet and Mongolia were brought under the jurisdiction of the Qing Dynasty. So Inner Mongolia and Tibet became the same country, and it makes easier to have religious exchanges between regions, so Tibetan temples influenced Inner Mongolia temples in the western region more than Han Buddhist temples compare with the eastern region.

Moreover, in terms of the building's kind, these two temples have many buildings that pay attention to religious academic teaching, such as Exotoric Buddhism Hall, Esoteric Buddhism Hall, Agwaa Hall, Lamrim Hall. Therefore, when paying attention to the teaching of Buddhism, these temples also completely imitate the free arrangement plan of temples in Tibet.

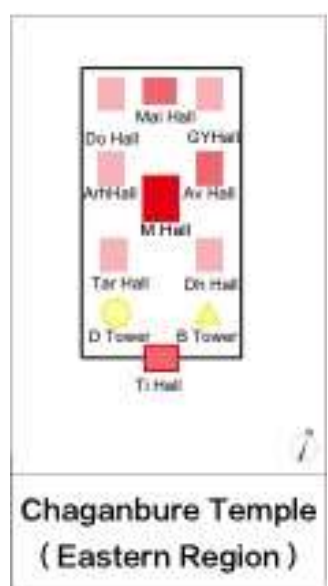

Figure 11. Model Figure of League Level/Integrated/Symmetric Type Temples Source: Inner Mongolian Tibetan Buddhist Architecture (I), (II), (III).

29. Yongping Wang, Tibetan Buddhist Architecture In Lhasa (Southeast University Press, 2019), 58-59. 


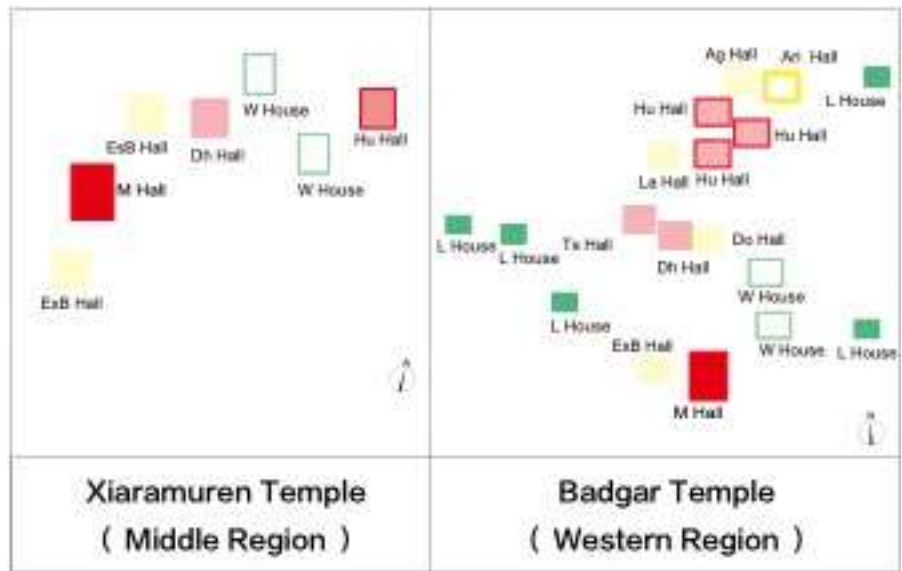

Figure 12. Model of League Level/Integrated/Asymmetric Type Temples

Source: Inner Mongolian Tibetan Buddhist Architecture (I), (II), (III).

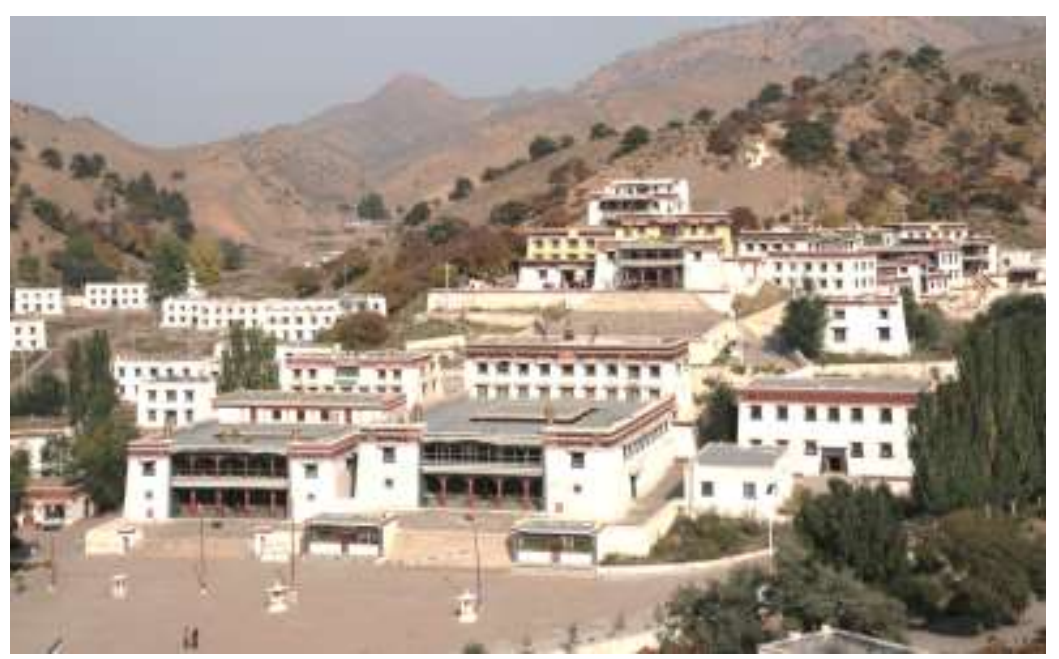

Figure 13. Badgar Temple

Source: Inner Mongolian Tibetan Buddhist Architecture (I), (II), (III).

The Separated Type

There are nine temples of this type. In these nine temples, three temples are in the western region, one is in the middle region, and five are in the eastern region (Figure 14). 


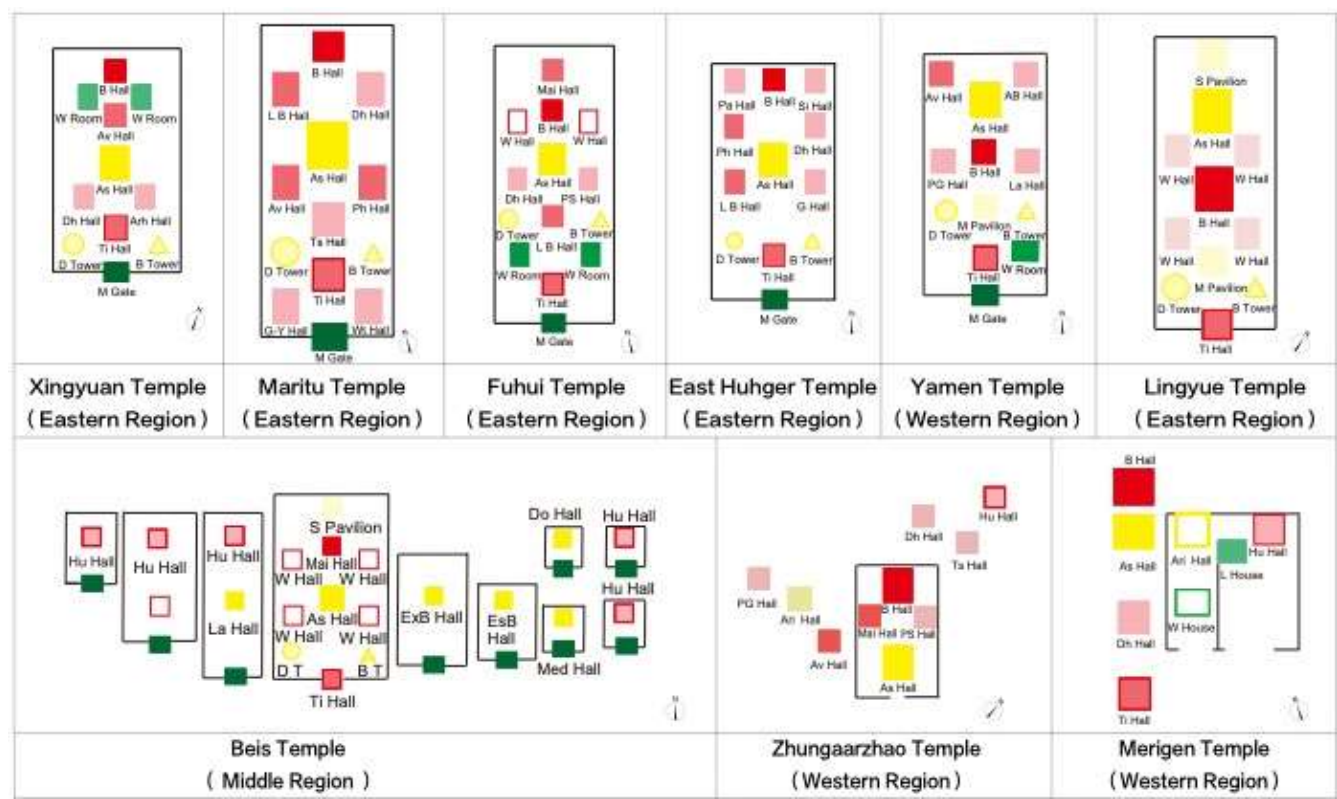

Figure 14. Model Figure of League Level/Seperated Type Temples

Source: Inner Mongolian Tibetan Buddhist Architecture (I), (II), (III).

In the seven temples other than the Zhungaarzhao Temple and Merigen Temple in the western region, all the buildings are arranged symmetrically along the axis, and walls surround the site. The Tianwang Hall is placed in front of the temple, and the Bell Tower and the Drum Tower are placed symmetrically behind the Tianwang Hall, as in the provincial temple. The buildings with the high level of Buddha statues, such as Tathagata and Bodhisattva, are arranged along the axis. And the buildings with the other Buddha statues, such as Vajra, Mother Buddha, disciples, patriarchs, and local gods, are arranged on both sides of the axis symmetrically. And all these characters are the same as the Han Buddhist temple style.

Most of these temples are in the eastern region. They had a close relationship with the Qing government at the initial stage of construction, so they received a lot of assistance from the Qing Dynasty. As a result, the temple is mainly built based on the Han Buddhist temple style. However, only the Beis Temple in the middle region has buildings that pay attention to teaching Buddhism. But is still based on the central axis and symmetrically arranged left and right according to the way of Han Buddhist temples (Figure 15). 


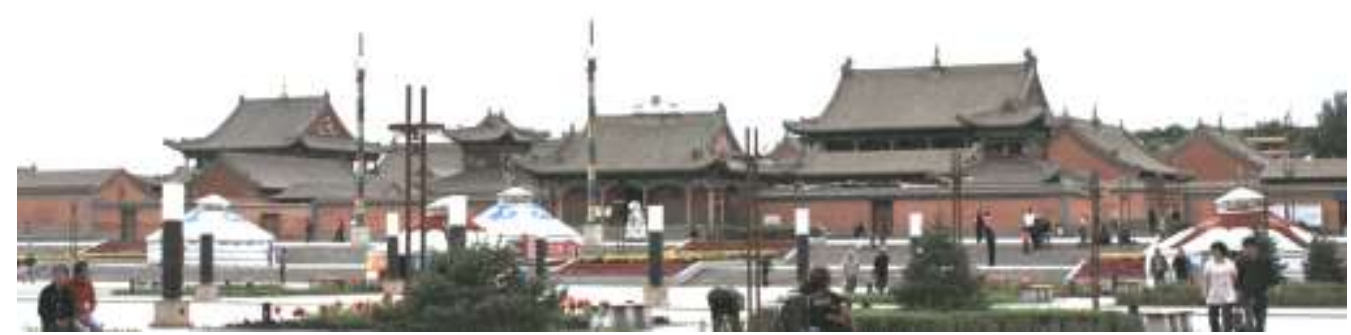

Figure 15. Beis Temple

Source: Inner Mongolian Tibetan Buddhist Architecture (I), (II), (III).

In the Zhungaarzhao Temple and the Merigen Temple (Figure 16), Only the main buildings are arranged along the axis, and as the building moves away from the axis, low-level buildings are freely allocated. The walls surrounding the site, the Monastery Gate, the Bell Tower, and the Drum Tower are omitted, and the Hutuhetu Hall is located away from the Mahavira Hall. Through these characteristics, the two temples can be regarded as the Compromise temple style.

Both temples are in the western region. In particular, the construction of Zhungaarzhao Temple was built shortly after the introduction of Buddhism by the Mongolian Khan at that time, but it was a certain distance from the middle region. And the Merigen Temples was also built by the nobles in the western region ${ }^{30}$. Therefore, the construction of the Mahavira Hall was not confined to Integrated Type but Separated Type. Combined with the Tibetan temples style, all buildings are not rigidly adhered to the axis.

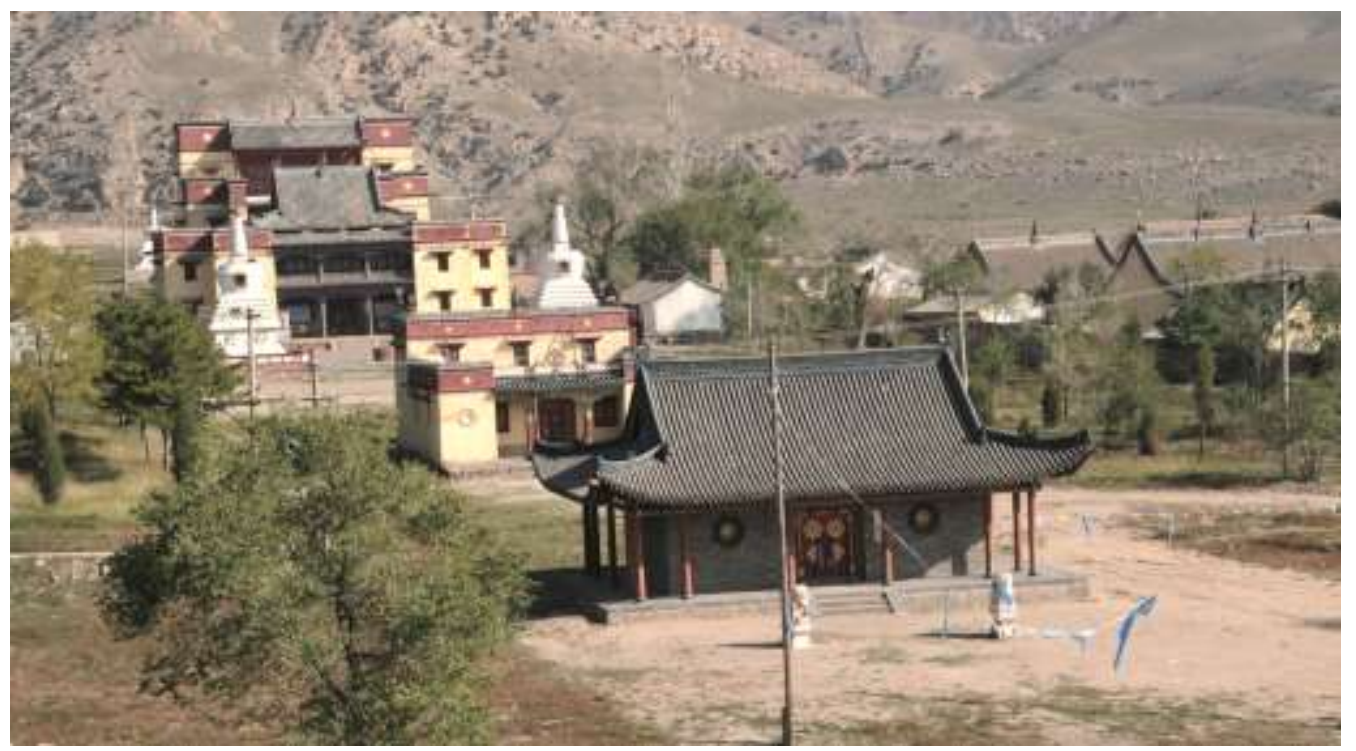

Figure 16. Merigen Temple

Source: Inner Mongolian Tibetan Buddhist Architecture (I), (II), (III).

30. Galalu Se, History of Culture and Art of Mongolian Buddhism (I) (Inner Mongolia People's Publishing House, 2013), 17-21. 


\section{The Banner Level Temple}

There are 18 Banner Level Temple. In these temples, it can be confirmed that four temples are the Integrated/Symmetric Type Temple, two temples are Integrated/ Asymmetric Type Temples, and two temples are Separated Type Temples.

The Integrated/Symmetric Type

Among the four temples of this type, three are in the middle region, and one and the eastern regions (Figure 17). Except for the Xiara Temple, in the other six temples, all the buildings are arranged symmetrically along the axis, and walls surround the site. The Tianwang Hall is placed in front of the temple, and the Wing house and Wing Hall, Lama house are arranged symmetrically on both sides. Even the building enshrined Tathagata and Bodhisattva, the Bell Tower, and the Drum Tower are omitted in these Banner temples, but it is still considered the Han Buddhist temple style. At the Xiara Temple, the buildings are not neatly arranged along the axis, and the Tianwang Hall, the Bell Tower, and the Drum Tower are omitted, and Hutuhetu Hall and two Buddhism Halls in the temple. So, it is considered the Compromise temple style. No matter what style, these Banner level temples omit some high-grade buildings compared with league level temples of the same type.

Moreover, most of these temples are in the middle region. Therefore, as same as many temples in the middle region of high-level temples, the Assembly Hall and Buddha Hall are integrated as Mahavira Hall. However, because the temple level is Banner level, many buildings have been omitted.

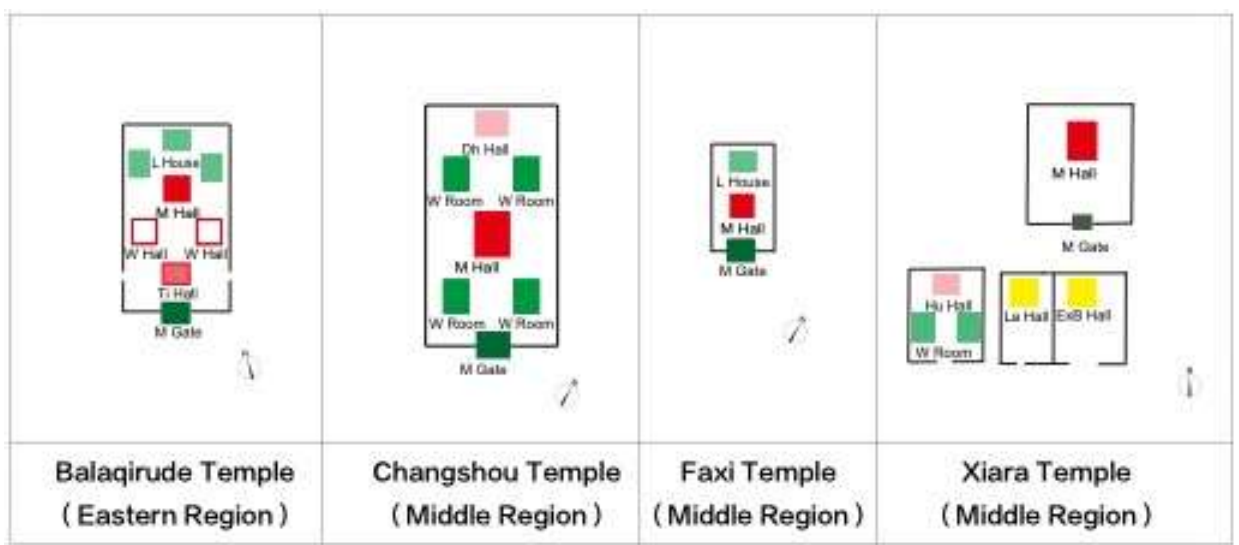

Figure 17. Model Figure of Banner Level/Integrated/Symmetric Type Temples Source: Inner Mongolian Tibetan Buddhist Architecture (I), (II), (III).

The Integrated/Asymmetric Type

In this form, the buildings of the Agui Temple and the Badanjiren Temple are freely arranged along the terrain, and the walls surrounding the site, the Monastery Gate, the Tianwang Hall, the Bell Tower, and the Drum Tower are omitted. They are considered as the Tibetan temple style (Figure 18). 
These two temples are in the western region where is close to Tibet, so it's easier to accept the influence of Tibetan temples, so their arrangement plans are freely arranged along the terrain. In terms of building kind, the Agui temple has many buildings dedicated to high-level Buddha statues. This is determined by its construction background. Differ from other temples, the Agui temple is the only Sakya Tibetan Buddhist temple in Inner Mongolia, and it was built as a League Level Temple. Later, because Gelug Tibetan Buddhism became the main sect in Tibet, the temple was included in the management of Yanfu temple, a Gelug Tibetan Buddhist temple, so it became a Banner level temple ${ }^{31}$. But it still retains the buildings with the high-level Buddha statues of the construction period. In contrast, the Badanjiren Temple of the Banner Temple omits many buildings, and the arrangement plan becomes simple.

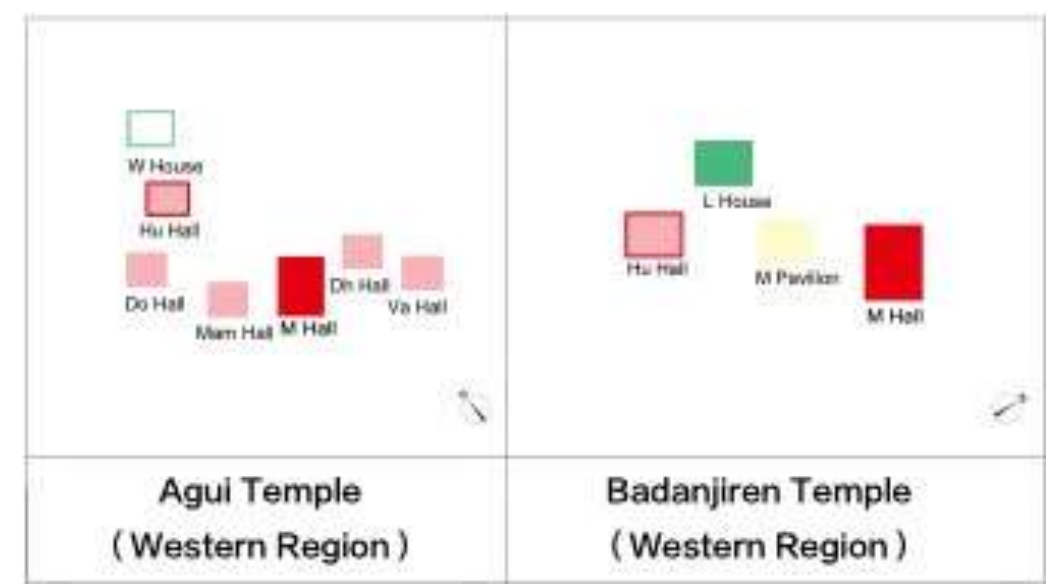

Figure 18. Model Figure of Banner Level/Integrated/Asymmetric Type Temples Source: Inner Mongolian Tibetan Buddhist Architecture (I), (II), (III).

The Separated Type

The two temples of this type, both are in the eastern region. The buildings are arranged along the axis. The Tianwang Hall and the Monastery Gate are arranged in front of the site. Moreover, the Bell Tower and the Drum Tower are arranged on both sides behind them. Furthermore, the Arhat Hall and the Dharmapalas Hall are arranged symmetrically behind them. They are considered the Han Buddhist temple style. Compared with the League Level temples of the same type, these Banner Level temples omit some high-grade buildings, such as the building enshrined Tathagata and Bodhisattva (Figure 19).

The reason why the two temples have the above characteristics is that they are in the eastern region, so they are easier to influenced by Han Buddhist temples, and they are also Banner Level temples, so many buildings are omitted compared with higher grade temples of the same type.

31. Refer to remarks of Agui Temple in Table 2. 


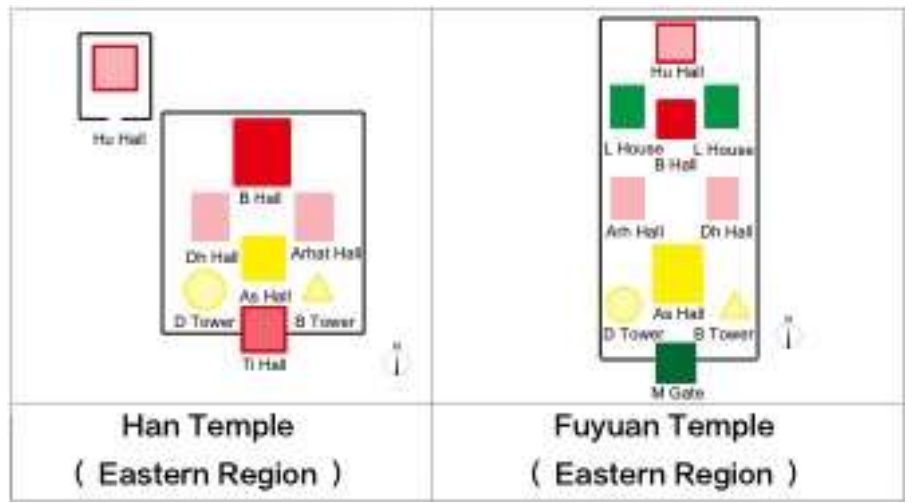

Figure 19. Model Figure of Banner Level/Seperated Type Temples

Source: Inner Mongolian Tibetan Buddhist Architecture (I), (II), (III).

\section{Conclusions}

This paper defines the arrangement plans characteristics of Buddhist temples in Inner Mongolia by clarifying the architectural grade and building category of 30 well preserved old Buddhist temples in the whole region of Inner Mongolia and analyzing their architectural forms of arrangement plan.

Results-wise, this article suggests that these temples could be divided into three levels: Province Level, League Level, and Banner Level based on the social background of the history time and the construction background of each temple. Furthermore, 56 kinds of temple buildings among these 30 temples were divided into three types according to their functions. Lastly, the arrangement plan has been modeled, which is also classified into different types. In accordance with the main buildings among the 56 classifications, the arrangement form of the temple has shown to be divided into Integrated Type and Separated Type. Importantly, Integrated Type could be divided into more detailed types like Symmetric Type and Asymmetric Type. And considering the level of temples, these temples are divided into seven types, and the arrangement plan of various types of these temples is compared and analyzed. The characteristic arrangement plans of these temples in different regions have been found through a comparative analysis of each level's temple arrangement of various types. It was analyzed in detail the characteristic of the arrangement plans of a wide variety of Inner Mongolia temples and systematically clarified the characteristics of the arrangement plans of Buddhist temple architecture in Inner Mongolia. The summary is as follows.

Among the temples, the most prestigious Province Level temples are in the middle region, the political center of Mongolia. Moreover, these temple buildings are built and arranged according to the arrangement plan of the Han Buddhist temple style.

The League Level temples and the Banner level temples are dispersed in the eastern, middle, and western regions, and three types of temples, Integrated/ Symmetric, Integrated/Asymmetric, and Separated, can be confirmed, and the arrangement plans differ greatly for each type. Even if the type is basically the 
same, the number and types of buildings tend to decrease as the temple level decreases.

Among the temples, the arrangement plan belonging to the Han Buddhist temple style, there are 1 Integrated/Symmetric Type Temple and 7 Separated Type Temples in League Level Temple, and 3 Integrated/Symmetric Type Temples and all the Separated Type Temples in Banner Level Temple.

The temples, which have the same arrangement plan as the Tibetan temple style, are all Integrated/asymmetrical temples of the League Level and Banner Level temples.

Among the temples, the arrangement plan belonging to the Compromise temple style, there are 6 Integrated/Symmetric Type Temples and 2 Separated Type Temples in League Level Temple, and 1 Integrated/Symmetric Type Temples of Banner Level Temple.

The regional characteristics of the arrangement plan of temples are mainly shown as follows: In the eastern region, which is near Beijing, all the temples are belonging to the Han Buddhist temple style; In the western region, which is near Tibet, the number of the Compromise temple style temples is the largest, but the number of the Tibetan temple style temples is also large (the Tibetan temple style temples number is largest compare with other regions). In the middle region, the number of temples that belong to the Han Buddhist temple style is the largest and have the Compromise temple style and the Tibetan temple style temples.

In the transition of the times, Mongolian temples were initially built in the Han Buddhist Style. Although the Tibetan temple style had influenced it, it had not been completely imitated. Instead, the Compromise temple style Temple combining Han Buddhist Style and the Tibetan temple style was built. Finally, the pure Tibetan temple style was built in Inner Mongolia.

From the above characteristics, the arrangement plan of Buddhist temples in Inner Mongolia is different due to the level of the temple, different regions, and times. The regional and time changes of these temples can also prove that the background of the times and the influence of the surrounding culture are the reasons behind the emergence of multi-form temples in Inner Mongolia. Moreover, through the comparative analysis of various forms, the characteristics of the temple arrangement plan in Inner Mongolia are systematically clarified.

In conclusion, the Inner Mongolia temple has a rich arrangement form, and according to the temple level and different regions and times, its form is also different. The main reason for this phenomenon is the historical background of Mongolia at that time and the influence of the surrounding ethnic architecture.

The comprehensive analysis of the arrangement characteristics of the Inner Mongolia temple and its reasons will provide a basis for the systematic study of Mongolian temple architecture. 


\section{Bibliography}

Akira, Suganuma. Mongolian Buddhist Travelogue. Shunmei Sha, 2004. [In Japanese.]

Baasansuren, H. Erdene Zuu: The Jewel of Enlightenment. 《Позитив》 агентлаг, 2011. [In Mongolian.]

Bao, Muping. Comprehensive Survey of Buddhist Temples at Western Inner Mongolia: A Study on the History of Mongolian Buddhist Architecture (Part 1). In Summaries of Technical Papers of Annual Meeting, 193-194. Architectural Institute of Japan, 2007. [In Japanese.]

. The process for Establishment of Buddhist Temple Ushin Dzuu and Its Spatial Structure: A Study on the History of Mongolian Buddhist Architecture (Part 2). In Summaries of Technical Papers of Annual Meeting, 195-196. Architectural Institute of Japan, 2007. [In Japanese.]

Berger, Patricia and Terese Tse Bartholomew. Mongolia the Legacy of Chinggis Khan. Hong Kong: C\&C Offset Printing Co., 1995.

Gajin, Nagao. Mongolian Academic Temple. Chuko Bunko, 1992. [In Japanese.]

Junko, Miyawaki. History of Mongolia-From the Birth of Nomads to Mongolia. Toui Shobo, 2002.10. [In Japanese.]

Lou, Qingxi. Chinese Palace Architecture. Yi Shu Jia Press, 1994. [In Chinese.]

Namusilai. History of Four Oirat Mongolia. Inner Mongolia People's Publishing House, 2011. [In Mongolian.]

History of Mongolia in Qing Dynasty. Inner Mongolia People's Publishing House, 2011. [In Mongolian.]

Rasurong, Daci Temple-Hyangarwa. Inner Mongolia Culture Press, 2013. [In Mongolian.]

Saiyinchaogetu. The Great Khan in the Late Northern Yuan Dynasty. Inner Mongolia Culture Press, 2014. [In Mongolian.]

Se, Galalu. History of Culture and Art of Mongolian Buddhism (I). Inner Mongolia People's Publishing House, 2013. [In Mongolian.]

Su, Bai. Archaeology of Tibetan Buddhist Temple. Cultural Relics Press, 1996. [In Chinese.]

Toa Archaeology Society Mongolian Survey Group. Notes of the Mongolian Plateau Crossing. Asahi Shimbun Press, 1945. [In Japanese.]

Tsultem, N. Mongolian Architecture. Ulan-Bator: State Publishing House, 1988.

Wang, Yongping. Tibetan Buddhist Architecture In Lhasa. Southeast University Press, 2019. [In Chinese.]

Wu, Baichun. A Brief History of the Mongolian Empire. Inner Mongolia People's Publishing House, 2011. [In Mongolian.]

Zhang, Pengju. Inner Mongolian Tibetan Buddhist Architecture (I), (II), (III). China Architecture \& Building Press, 2013. [In Chinese.]

Zhang, Yuhuan. Inner Mongolian Ancient Architecture. Tianjin University Press, 2009. [In Chinese.] 
